DOI 10.31558/2519-2949.2020.2.14

УДК 321.7:316.070:004.

ORCID ID: https://orcid.org/0000-0001-9799-9786

Стеблина Н. О., Донецький національний університет імені Василя Стуса

\title{
COVID-19 ТА ТРАНСФОРМАЦІЯ ЦИФРОВОГО ПОЛІТИЧНОГО ДИСКУРСУ УКРАЇНИ У 2020 Р.
}

\begin{abstract}
Цифровізачія політичного дискурсу в теорії може зменшувати диспропориію між репрезентацією офіиійних та неофічійних акторів у кризові часи, характерну для мас-медійного етапу розвитку дискурсу. Для того, щзоб перевірити иґю гіпотезу, було відстежено трансформацію українського иифрового політичного дискурсу у січні-травні 2020 р. Дані з иъього періоду порівнювалися із даними 2019 р. Матеріалом дослідження були тексти провідного суспільно-політичного видання «Украӥнська правда». Корпус текстів склав більше 10 тис. одиниць. Тексти оброблялися за допомогою програм, написаних мовою Руthоп. Вимірювалися чотири показники: диверсифікація, унікальність, збалансованість та вітчизняний фокус цифрового політичного дискурсу.

Показник диверсифікаиії порівняно із попереднім роком впав нижче середнього (1,2 у 2019 р.), із найнижчими показниками у березні-квітні (0,5-0,6). Показник унікальності - навпаки зріс, порівняно із 2019 р. $і$ залишався приблизно на одному й тому ж рівні-25-27\%. В період карантину ця характеристика в иілому співпала із характеристиками ЦПД під час «мертвого сезону» y 2019 р. I свідчить про більш низьку інтенсивність політичного життя. Також у березні-травні спостерігаємо меншу гетерогенність у складі найбільш згадуваних політичних акторів (це переважно - представники влади). Тим не мени, за показником збалансованості маємо найменший розрив між кількістю згадувань першої особи у рейтингу згадуваності (Зеленський) та другою (Кличко). А у березні-квітні - більшу вагу до внутрішніх тем (вітчизняний фокус - вищій, ніж середній показник у 2019 р.).

В результаті проведеного дослідження, можемо зазначити, щчо цифровий політичний дискурс Украӥни трансформувався внаслідок подій, пов'язаних із пандемією COVID-19. Бачимо, щчо взаємодія між політичними акторами була зведена до мінімуму, що може свідчити про недостатню залученість до взаємодії неофіціних акторів або ж про їхню «непомітність» у дискурсі.

Ключові слова: иифровий політичний дискурс, Украӥна, COVID-19, криза, політичний текст, «Українська правда»
\end{abstract}

Кризові часи, як правило, змінюють принципи функціонування політичного дискурсу. Як правило, це можна відстежити через репрезентацію політичних акторів - політичних суб'єктів та інститутів. Саме офіційні актори мають бути представлені у дискурсі найбільше: вони володіють останніми даними, вони мають уплив та статус, щоб контролювати ситуацію та ін. Це призводить до того, що політичний дискурс держави, в якому i удокризові часи непропорційно були представлені офіційні особи та інститути, стає ще більш нерівномірним, при цьому збільшується розрив між представленістю у ньому представників влади та владних інституцій та інших акторів (громадських активістів, експертів, опозиції та ін.). Тим не менш, цифровізація політичного дискурсу в теорії може зменшувати диспропорцію між репрезентацією офіційних та неофіційних акторів, адже технологічно як перші, так і другі, мають можливість висловлюватись через низку майданчиків у мережі, а отже, долучатися до формування порядку денного. Пандемія коронавірусу призвела до того, що численні інституції, підприємства та організації перевели свою діяльність (в тому числі, комунікативну) в онлайн, відтак, можемо припустити, що вони потенційно можуть бути представленими у політичному дискурсі збалансовано. Маючи дані щодо цифрового політичного дискурсу України 2019 року, зможемо це встановити у даному дослідженні.

Характеристики політичного дискурсу під час кризових ситуацій

Рівноцінне представлення інтересів усіх зацікавлених осіб під час кризової ситуації $є$ дуже важливим. Ефективна комунікація, що передбачає взаємодію багатьох суб'єктів та інституцій під час епідемії чи пандемії є надзвичайно важливою [16, с. 120]. “Для того, щоб досягти успіху

(C) Стеблина Н. О., 2020 
у питанні громадського здоров'я, важлива не тільки базова інформація, адже у часи нових інфекційних захворювань точна інформація може бути просто недоступною, експерти також можуть не дійти консенсусу щодо можливих ризиків та лікування, при цьому ЗМІ змагаються один з одним, можуть поширювати чутки - тим більше ускладному медійному оточенні, що формується Інтернетом та соціальними медіа» [16, с. 129] зазначають Лі та Баснят, що вивчали пандемію Н1N1. Також маємо враховувати, що під час кризових ситуацій, на інформування мають вплив час (адже повідомлення потрібно надавати якнайшвидше - в тому числі, щоб уникнути чуток або ж паніки) та відстань (важливо повідомляти про події з усього світу), за яких не випадає можливості вивчити проблему глибше, відредагувати написане та аналізувати та ін. [15, с. 164]. Ефект посилює «культура швидкості», за якої «жадобу швидкості неможливо заспокоїти» [23, с. 193].

Під час кризових ситуацій найбільше у політичному дискурсі репрезентовані еліти. Вони коментують події, є ключовими ньюзмейкерами, відтак, упливають на суспільну думку під час кризи, коли до політики та новин прикута увага більшої, ніж завжди аудиторії [7]. За такої кризової ситуації, як, наприклад, війна, саме офіційні джерела найбільше представлені у ЗМІ, при цьому журналісти, як правило, ставляться до інформації та позицій, що поширюють ці джерела, некритично [14], також можуть поширюватися пропагандистські меседжі [5, 74]. За такої «інформаційної гегемонії» [4] до мінімуму зводиться «альтернативна комунікація», яка важлива для щоденного життя, участі у політиці (індивідуально й колективно), для формування ідентичності та приналежності [5, с. 12]. Звісно, інформація з офіційних джерел за кризової ситуації, в тому числі пандемії, важлива, адже аудиторіям мають надаватися інструкції- «що робити фізично» та «регулююча інформація»- «як із кризою впоратися психологічно» [8, с. 29]. Тим не менш, для формування адекватного уявлення про те, що відбувається, потрібні й інші голоси, доповнення, фільтрація офіційної інформації. Лі та Баснят пишуть, що під час пандемії H1N1 була важлива диверсифікація провідних фреймів (від влади) та емоційних закликів, більш чіткий тематичний фреймінг, більше джерел інформації та ін. [16, с. 129]. Урядові ж організації, що поширюють повідомлення, мають прагнути до спільних інтерпретацій того, що відбулося, і співпрацюючи зі ЗМI, полегшувати загальну атмосферу кризи, - зазначають Геркен і ван дер Меєр, що досліджували кризу викликану Еболою [11, с. 173]. Паінтер і Кью вважають, що за часів пандемії важливо знижувати градус політичної напруги, бо за їхніми спостереженнями політична поляризація впливає на дотримання соціального дистанціювання [20]. Важливо також пам'ятати про дисбаланс між повідомленнями про COVID-19 та іншими темами у політичному дискурсі, при цьому перші можуть витісняти зокрема повідомлення про конфлікти та війну, тож «може скластися хибне враження про те, що старі проблеми вирішено. Відтак, країни, в яких тривають воєнні конфлікти, можуть зазнати ще більших проблем, адже тепер увагу їхнім подіям практично не приділяють» [6, с. 5-6]. При цьому під час пандемії держави більш зосереджені на внутрішніх справах, відтак внутрішня політика стає більш ізоляціоністською [13]. Хоча при тому, що пандемія змінить існуючий світопорядок, все ж вона може змусити більшість країн світу співпрацювати [21].

Карантин та викликані ним обмеження також потрібно враховувати, говорячи про політичний дискурс та його різноманіття. Приміром, уже більш ніж 10 років Freedom House констатує зниження оцінок за дотримання прав і свобод у багатьох країнах по всьому світу. А пандемія коронавірусу, на думку фахівців організації, може призвести до «нових викликів демократії та правам людини». Причому це стосується не тільки авторитарних чи тоталітарних країн, але й демократичних [9]. Про це ж зазначає й Ільяс: «Економічна криза, викликана пандемією, загрожує ще більшій нерівності, при цьому копцепти ліберальних економік та демократій опиняються під питанням, оскільки у все більшій кількості країн обмежують громадські свободи.., тож система вже не працюватиме, як раніше» [13].

Погіршення ситуації із дотриманням політичних та громадянських прав та свобод відображається і на якості політичної комунікації. При цьому ще до пандемії експерти констатували наявність цієї проблеми. Приміром, фахівці Інституту Ройтерз дійшли висновків, що майже кожен третій мешканець світу (29\%) уникає новин [19], також третина споживачів новин вважає політичні повідомлення неважливими [17]. Дослідники Pew Research Center зазначають, що 44\% аудиторій у 38 країнах світу сприймають політичні новини як заангажовані [18]. Тут можна згадати й про феномен disempowerment - відчуття власної безсилості щодо змін, зокрема, у політичному житті власної країни [10]. На якість політичної комунікації впливає маркетизація політики [22] та новин [12].

Щодо ситуації в Україні, то за спостереженнями медійних організацій, більшість спікерів, що коментують COVID-19 - регіональні посадовці та політики [3]. При цьому темі коронавірусу в українських 3МІ присвячувалося 58,5\% у березні 2020 і 27\% - у травні [2]. 
Мета, матеріал та метод

Беручи до уваги усе, зазначене вище, маємо відповісти на питання, як саме пандемія COVID-19 позначилася на українському цифровому політичному дискурсі, зокрема, беручи до уваги показники диверсифікації (наявність у ЦПД більш ніж одного політичного актора), унікальності (наявність у ЦПД постійних та непостійних акторів), збалансованості (співвідношення між відсотком уваги до другого та першого спікера та змінність цих спікерів) та вітчизняного фокусу (відсоток повідомлень про внутрішні події).

Матеріалом для нашого дослідження стало провідне українське суспільно-політичне видання «Українська правда». За допомогою програм, написаних мовою Python за січень - травень 2020 (до 23 травня) було зібрано 10046 текстів новин і проаналізовано такі показники:

- диверсифікації - середня кількість згадок про політичних акторів у заголовках;

- унікальності - відсоток унікальних згадок політичних акторів до кількості загальних згадок;

- збалансованості- співвідношення відсотка згадок другого в рейтингу згадуваності політичного актора до другого;

- вітчизняного фокусу - співвідношення відсотка згадок внутрішніх політичних акторів до зовнішніх.

Результати

Диверсифікачія

Згідно із попередніми дослідженнями ЦПД України, середній показник диверсифікації за минулий рік склав 1,1. Порівняно із 2005 роком він продовжує знижуватися (у 2005 році він становив - 2,3). При цьому можливі сезонні коливання, коли показники на початку та в кінці року та влітку (у так званий «мертвий сезон»: періоди канікул, свят та відпусток) можуть бути меншими. Збільшення за показником у минулому році співпадали із періодами передвиборчих кампаній та виборами, початком роботи нового уряду та нової ради.

Цього ж року бачимо разючу відмінність (мал. 1).

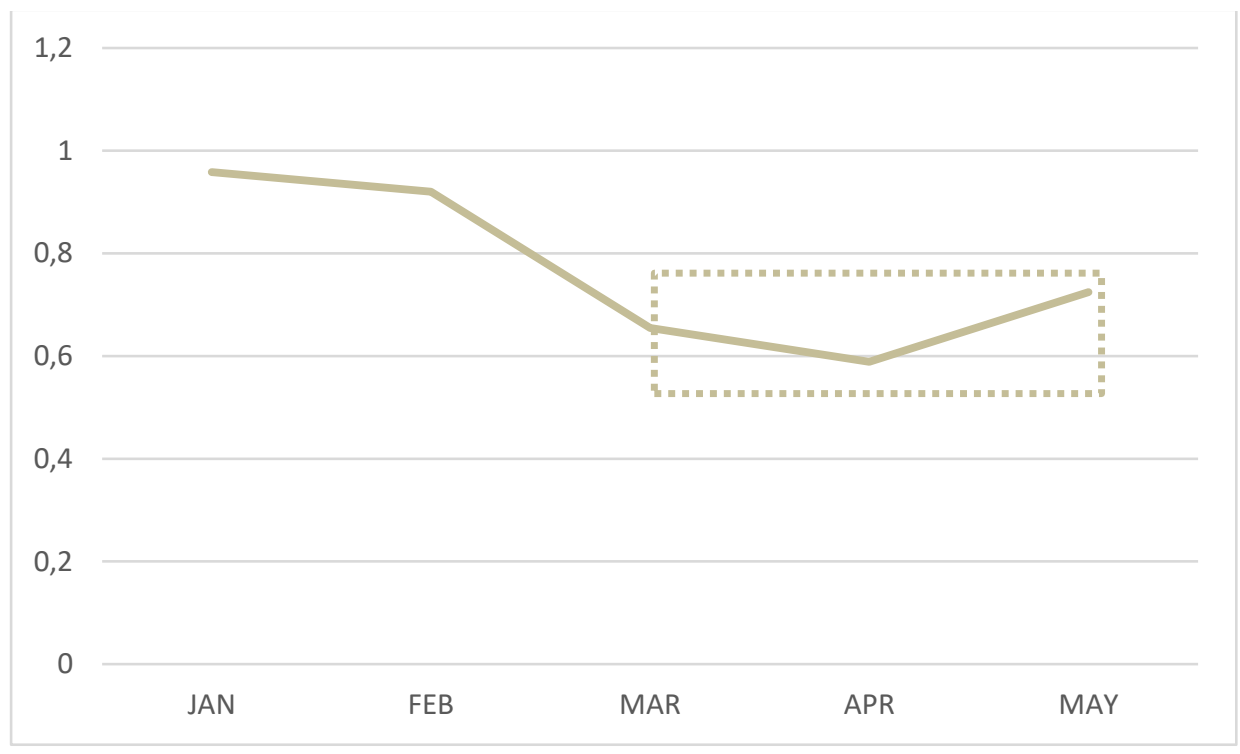

Мал 1. Диверсифікація цифрового політичного дискурсу Украӥни (січень-травень 2020)

Показник диверсифікації на початку року становив 0,9 (0,89- у січні минулого року), проте пізніше - у березні-травні - зростання не відбулося, навпаки, показники впали. Тож зниження інтенсивності політичного життя уплинуло і на політичний дискурс, відтак цифровий політичний дискурс України і досі залишається залежним від офлайнового життя.

Унікальність

У 2019 році ми побачили негативну кореляцію між показником диверсифікації та унікальності. Тож чим більша унікальність, тим менша диверсифікація. Тож у періоди більш інтенсивної взаємодії до ЦПД долучаються переважно одні й ті ж самі актори. Також у минулому році середній показник унікальності становив 17\%, що означає, що взаємодія у ЦПД відбувається переважно між одними і тими ж акторами. Тут так само були зафіксовані сезонні коливання - найбільший показник на початку року, а також більші за середне показники у грудні та серпні. Знову ж таки, оскільки для ЦПД характерний режим роботи 24/7, обсяг інформації лишається тим самим 
(із незначними коливаннями), проте характер інформування змінюється через те, що ключові актори менше представлені. Або ж, як зазначав Ж. Бодрійяр, відбувається ксерокопіювання смислу, коли «ідея прогресу зникла, але сам прогрес - триває» [1].

За цим показником також спостерігаємо зміну у 2020 році (мал. 2).

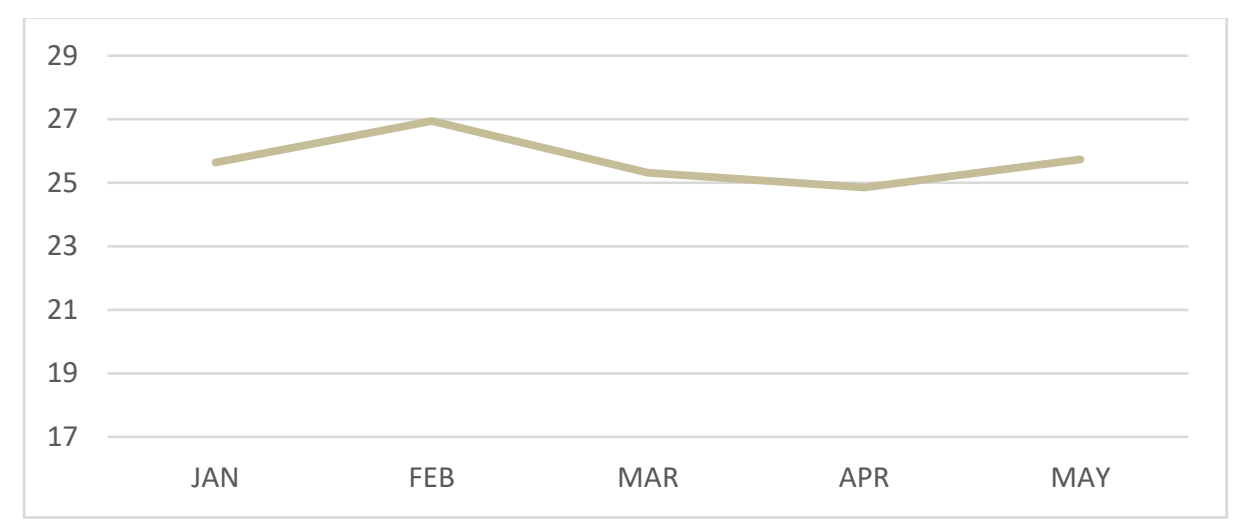

\section{Мал 2. Унікальність цифрового політичного дискурсу Украӥни} (січень-травень 2020)

Якщо у 2019 році унікальність ЦПД почала знижуватися з лютого, що у 2020 році цього не відбулося. I показник залишався приблизно на одному й тому ж рівні - 25-27\%. Це означає, що в період карантину ця характеристика ЦПД в цілому співпала із характеристиками ЦПД під час «мертвого сезону».

Хоча, звісно, це може свідчити й про більше залучення епізодичних політичних акторів до ЦПД. Проте чи приділяється їм достатня увага? Про це можемо дізнатися, вивчивши показник збалансованості.

Збалансованість

Оскільки у 2019 році відбулася зміна влади, то ми зафіксували найменший розрив між першою та другою фігурою у рейтингу згадуваності у квітні (Зеленський - Порошенко) - 0,7 у квітні. Проте середнє склало 0,29, оскільки після виборів різниця між кількістю згадок стабілізувалася.

У 2020 році також маємо найбільший розрив у 0,5 у квітні, і в цілому показник вищий за минулорічне середнє $-0,3$. Із падінням у травні до 0,25 (мал. 3 ).

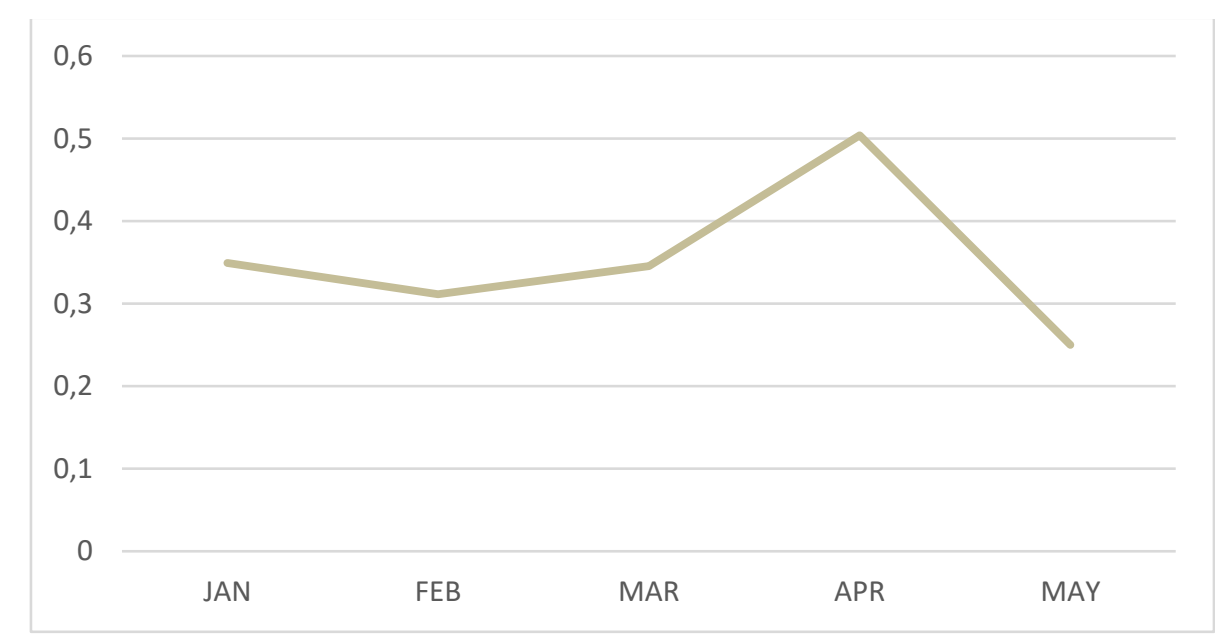

Мал 3. Збалансованість цифрового політичного дискурсу Украӥни (січень-травень 2020)

Ці дані свідчать про те, що у 2020 р поряд із першою фігурою у рейтингу (Зеленський) присутні також і значимі актори другого плану, які, звісно, не можуть конкурувати із ним за кількістю уваги, проте все ж також постійно фігурують у ЦПД, є впізнаваними та ін.

Склад найбільш популярних акторів дозволяє зробити висновок про зменшення гетерогенності ЦПД у період карантину (див табл 1). 
Топ-5 найбільш популярних акторів

\begin{tabular}{|c|c|c|c|c|c|}
\hline & $J A N$ & $F E B$ & $M A R$ & $A P R$ & MAY \\
\hline Зеленський & 146 & 151 & 136 & 129 & 136 \\
\hline Гончарук & 51 & 47 & 33 & & \\
\hline Порошенко & 39 & 31 & & & \\
\hline Шеремет & 27 & & & & \\
\hline Янукович & 13 & & & & \\
\hline Срмак & & 21 & 31 & 40 & 30 \\
\hline Богдан & & 19 & & & \\
\hline Шмигаль & & & 47 & & 24 \\
\hline Кличко & & & 45 & 65 & 34 \\
\hline Саакашвілі & & & & 28 & 28 \\
\hline Венедиктова & & & & 25 & \\
\hline Чорновол & & & & 25 & \\
\hline
\end{tabular}

Як правило, другою особою у рейтингу згадуваності $\epsilon$ прем'єр-міністр. Проте за часів карантину ситуація змінюється - i на перший план виходить мер Києва, що може свідчити про більшу сконцентрованість ЦПД на локальних подіях. Хоча, звісно, зміна прем'єрів також могла датися взнаки.

Цікаво також, що більш гетерогенним дискурс $є$ у січні, коли окрім представників влади у топ-5 входять й колишні президенти Порошенко та утікач-Янукович, і вбитий журналіст Шеремет. 3 березня по травень у топ-5 входили тільки представники влади (центральної чи місцевої) та силових структур за винятком квітня, коли однакову кількість згадувань набрали генеральна прокурорка Венедиктова та колишня народна депутатка Чорновол - узв'язку із імовірним підпалом офісу «Партії регіонів».

\section{Вітчизняний фокус}

Кількість згадок про вітчизняних акторів в українському ЦПД, як правило, переважає кількість згадок про зарубіжних, тим не менш, можемо констатувати, що у найбільш важливі періоди ця різниця збільшується. Наприклад, у 2019 році найбільшим показник вітчизняного фокусу був теж під час передвиборчих кампаній та виборів. Також і в 2020 бачимо зростання уваги до вітчизняних політичних акторів (мал. 4).

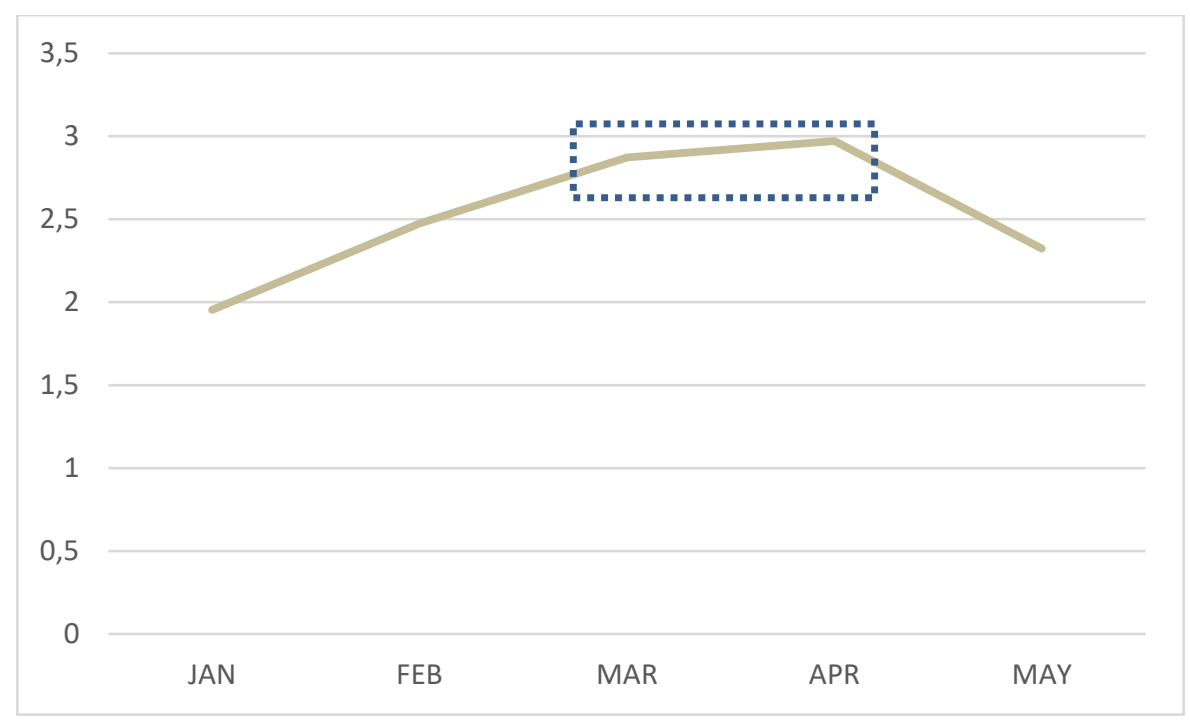

Мал 4. Вітчизняний фокус цифрового політичного дискурсу Украӥни (січень-травень 2020)

У березні-квітні показник більший за середнє у 2019 р. 


\section{Висновки}

В результаті проведеного дослідження, можемо зазначити, що цифровий політичний дискурс України трансформувався внаслідок подій, пов'язаних із пандемією COVID-19. Про це свідчить порівняльний аналіз за цими ж самими показниками у 2019 р. Зокрема ми бачимо серйозне падіння диверсифікації ЦДП, а отже взаємодія між політичними акторами була зведена до мінімуму, що може свідчити про недостатню залученість до взаємодії неофіційних акторів або ж про їхню «непомітність» у дискурсі. Звісно, можемо також пояснювати подібний показник новизною теми, іiі непередбачуваністю та, звісно, великим обсягом інформації, який варто було переробляти. Тож перевага надавалася тим джерелам, які могли надати попередньо оброблену і привабливо «упаковану» інформацію про пандемію. За такої ситуації у ЦПД можуть домінувати фрейми еліт, а інші точки зору - ігноруватися. I це також можна сприймати як ще один «виклик демократії» (використовуючи термінологію Freedom House.

Також бачимо значну представленість еліт у ЦПД під час пандемії- зі зниженням його гетерогенності під час карантину, а також знаходимо підтвердження тезі про більшу внутрішню ізоляцію дискурсу, його сконцентрованість на локальних проблемах.

Можемо констатувати, що наявність технологічних платформ для взаємодії у межах ЦПД мало використовується, й за показниками унікальності та диверсифікації бачимо таку ж низьку інтенсивність політичного життя, що й за часів так званого «мертвого сезону». Відтак, цифровий політичний дискурс продовжує залежати від офлайнового порядку денного.

\section{Бібліографічний список:}

1. Бодрийяр, Ж. Прозрачность зла. Москва: Добросвет, 2020.

2. Голуб, O. COVID-19 відходить на другий план. Звіт з моніторингу онлайн-медіа. IMI.

URL: https://imi.org.ua/monitorings/covid-19-vidhodyt-na-drugyj-plan-zvit-z-monitoryngu-onlajn-media-i33275 (дата звернення: 1.06.2020).

3. IMI. 39\% спікерів у новинах про коронавірус - регіональні посадовці та політики: дослідження IMI. URL: https://imi.org.ua/monitorings/39-spikeriv-v-novynah-pro-koronavirus-regionalni-chynovnyky-ta-politykydoslidzhennya-imi-i32888 (дата звернення: 1.06.2020).

4. Лалл, Д. Мас-медіа, комунікачія, культура: глобальний підхід. Київ: К. І. С., 2002.

5. Bailey, O., Cammaerts, B., \& Carpentier, N. Understanding Alternative Media. New York: Open University Press, 2008.

6. Bolder, P. (2020). COVID-19 and World Peace: An Overture to a New Era or Business as Usual? Hague Centre for Strategic Studies. URL: https://hcss.nl/report/covid-19-and-world-peace-overture-new-era-or-businessusual (дата звернення: 1.06.2020). DOI:10.2307/resrep24189

7. Calabrese, A., Burke, B. American Identities: Nationalism, the Media, and the Public Sphere. Journal of Communication Inquiry. 1992. № 16(2). P. 52-73. DOI:10.1177/019685999201600205

8. Coombs, T. Parameters for crisis communication. In T. Coombs, \& S. Holladay, Handbook of Crisis Communication. Oxford: Blackwell Publishing, 2010. P. 17-53.

9. Freedom House. Democracy during Pandemic. URL: https://freedomhouse.org/issues/democracy-duringpandemic (дата звернення: 1.06.2020).

10. Gans, H. Democracy and the News. New York: Oxford University Press, 2004.

11. Gerken, F., van der Meer, T. Crisis Frame Dynamics: Frame Diversity in News Media and the Role of Governmental Actors. Political Science. 2019. № 2(2). P. 149-180. DOI:10.30658/jicrcr.2.2. 1999.

12. Iggers, J. Good News, Bad News. Journalism. Ethics and the Public Interest. Boulder, Colo.: Westview Press,

13. Ilyas, A. Covid-19 Pandemic: Emergence of a New Geopolitical Perspective. Sustainable Development Policy Institute. URL: https://www.jstor.org\%2Fkbart\%2Fcollections\%2Fsustainability-backfilecollection\%3FcontentType\%3Dresearch_reports\&usg=AOvVaw3k7HWb8YWz2d-xB3pWMKFb (дата звернення: 1.06.2020). DOI:10.2307/resrep24375

14. Johnson, J., Kaye, B. Wag the Blog: How Reliance on Traditional Media and the Internet Influence Credibility Perceptions of Weblogs Among Blog Users. Journalism \& Mass Communication Quarterly. 2004. № 81(3). P. 622-642. DOI:10.1177/107769900408100310

15. Katz, E., Liebes, T. “No More Peace!": How Disaster, Terror and War Have Upstaged Media Events. International Journal of Communication. 2007. № 1. P. 157-166.

16. Lee, A., Chyi, H. When Newsworthy is Not Noteworthy. Examining the value of news from the audience's perspective. Journalism Studies. 2013. № 15(6). P. 807-820.

17. Lee, S., Basnyat, I. From Press Release to News: Mapping the Framing of the 2009 H1N1 A Influenza Pandemic. Health Communication. 2012. № 28(2). P. 119-132. DOI:10.1080/10410236.2012.658550

18. Mitchell, A. S. (2018). Publics Globally Want Unbiased News Coverage, but Are Divided on Whether Their News Media Deliver. URL: http://www.pewglobal.org/2018/01/11/publics-globally-want-unbiased-news-coveragebut-are-divided-on-whether-their-news-media-deliver/ (дата звернення: 1.06.2020). 
19. Newman, N. Reuters Institute Digital News Report 2017. Oxford: Reuters Institute for the Study of Journalism, 2017.

20. Painter, M., Qiu, T. Political beliefs affect compliance with COVID-19 social distancing orders. Vox.

URL: https://voxeu.org/article/political-beliefs-and-compliance-social-distancing-orders (дата звернення: 1.06.2020).

21. Shakeel, Ramay, A. Future of Global Order. Sustainable Development Policy Institute.

URL: https://www.jstor.org\%2Fkbart\%2Fcollections\%2Fpli-backfile-collection\&usg=AOvVaw35dTgf_Rr5-

5N7sWvVNSFe DOI:10.2307/resrep24364.5

22. Thompson, M. Enough Said: What's Gone Wrong with the Language of Politics? New York: St. Martin's Press, 2016.

23. van Dejk, J. A. The Network Society. Social Aspects of New Media. London: Thousand Oaks, 2006.

\section{References:}

1. Baudrillard, J. Prozrachnost' zla. Moskva: Dobrosvet, 2020.

2. Golub, O. COVID-19 vidxody`t’ na drugy`j plan. Zvit z monitory`ngu onlajn-media. IMI.

URL: https://imi.org.ua/monitorings/covid-19-vidhodyt-na-drugyj-plan-zvit-z-monitoryngu-onlajn-media-i33275 (дата звернення: 1.06.2020).

3. IMI. 39\% spikeriv u novy`nax pro koronavirus - regional`ni posadovci ta polity`ky`: doslidzhennya IMI. URL: https://imi.org.ua/monitorings/39-spikeriv-v-novynah-pro-koronavirus-regionalni-chynovnyky-ta-politykydoslidzhennya-imi-i32888 (дата звернення: 1.06.2020).

4. Lall, D. Mas-media, komunikatsiya, kul'tura: hlobal'nyy pidkhid. Kyiv: K. I. S., 2002. - 264 p.

5. Bailey, O., Cammaerts, B., \& Carpentier, N. Understanding Alternative Media. New York: Open University Press, 2008.

6. Bolder, P. (2020). COVID-19 and World Peace: An Overture to a New Era or Business as Usual? Hague Centre for Strategic Studies. URL: https://hcss.nl/report/covid-19-and-world-peace-overture-new-era-or-businessusual (дата звернення: 1.06.2020). DOI:10.2307/resrep24189

7. Calabrese, A., Burke, B. American Identities: Nationalism, the Media, and the Public Sphere. Journal of Communication Inquiry. 1992. № 16(2). P. 52-73. DOI:10.1177/019685999201600205

8. Coombs, T. Parameters for crisis communication. In T. Coombs, \& S. Holladay, Handbook of Crisis Communication. Oxford: Blackwell Publishing, 2010. P. 17-53.

9. Freedom House. Democracy during Pandemic. URL: https://freedomhouse.org/issues/democracy-duringpandemic (дата звернення: 1.06.2020).

10. Gans, H. Democracy and the News. New York: Oxford University Press, 2004.

11. Gerken, F., van der Meer, T. Crisis Frame Dynamics: Frame Diversity in News Media and the Role of Governmental Actors. Political Science. 2019. № 2(2). P. 149-180. DOI:10.30658/jicrcr.2.2. 1999.

12. Iggers, J. Good News, Bad News. Journalism. Ethics and the Public Interest. Boulder, Colo.: Westview Press,

13. Ilyas, A. Covid-19 Pandemic: Emergence of a New Geopolitical Perspective. Sustainable Development Policy Institute. URL: https://www.jstor.org\%2Fkbart\%2Fcollections\%2Fsustainability-backfile-collection \%3FcontentType\%3Dresearch_reports\&usg=AOvVaw3k7HWb8YWz2d-xB3pWMKFb (дата звернення: 1.06.2020). DOI:10.2307/resrep24375

14. Johnson, J., Kaye, B. Wag the Blog: How Reliance on Traditional Media and the Internet Influence Credibility Perceptions of Weblogs Among Blog Users. Journalism \& Mass Communication Quarterly. 2004. № 81(3). P. 622-642. DOI:10.1177/107769900408100310

15. Katz, E., Liebes, T. “No More Peace!": How Disaster, Terror and War Have Upstaged Media Events. International Journal of Communication. 2007. № 1. P. 157-166.

16. Lee, A., Chyi, H. When Newsworthy is Not Noteworthy. Examining the value of news from the audience's perspective. Journalism Studies. 2013. № 15(6). P. 807-820.

17. Lee, S., Basnyat, I. From Press Release to News: Mapping the Framing of the 2009 H1N1 A Influenza Pandemic. Health Communication. 2012. № 28(2). P. 119-132. DOI:10.1080/10410236.2012.658550

18. Mitchell, A. S. (2018). Publics Globally Want Unbiased News Coverage, but Are Divided on Whether Their News Media Deliver. URL: http://www.pewglobal.org/2018/01/11/publics-globally-want-unbiased-news-coveragebut-are-divided-on-whether-their-news-media-deliver/ (дата звернення: 1.06.2020).

19. Newman, N. Reuters Institute Digital News Report 2017. Oxford: Reuters Institute for the Study of Journalism, 2017.

20. Painter, M., Qiu, T. Political beliefs affect compliance with COVID-19 social distancing orders. Vox. URL: https://voxeu.org/article/political-beliefs-and-compliance-social-distancing-orders (дата звернення: 1.06.2020).

21. Shakeel, Ramay, A. Future of Global Order. Sustainable Development Policy Institute.

URL: https://www.jstor.org\%2Fkbart\%2Fcollections\%2Fpli-backfile-collection\&usg=AOvVaw35dTgf_Rr5-

5N7sWvVNSFe DOI:10.2307/resrep24364.5

22. Thompson, M. Enough Said: What's Gone Wrong with the Language of Politics? New York: St. Martin's Press, 2016.

23. van Dejk, J. A. The Network Society. Social Aspects of New Media. London: Thousand Oaks, 2006. 
Steblyna N. O. COVID-19 and Ukrainian digital political discourse transformation in 2020

A political discourse digitalization potentially may lead to decreasing a disproportion in official and non-official actors representation in a crisis times, which was observed in mass-media period of the discourse development. To check this hypothesis, the Ukrainian digital political discourse transformation was observed between January-Mau 2020. These data was compared with 2019 data. A corpus of texts was formed form a prominent Ukrainian social and political site «Ukrayins 'ka pravda» (more than 10 thousand items). The texts were processed with the help of Python programs. Four indicators were measured: diversification, uniqueness, balance and domestic focus.

The diversification indicator decreased in comparison with 2019 (1,2). In March-April 2020 the indicator had the lowest rate $(0,5-0,6)$. And vice versa, the uniqueness indicator increased and was stable in 2020 - 25-27\%. In the quarantine period this characteristic coincided with the Ukrainian digital political discourse characteristics during so called «dead season» (holidays, vacations) in 2019. This shows a lower intensity of political life. Additionally, in March-May lower heterogeneity in a list of the most popular political actors is observed (officials mainly). However, there is a smaller gap between the first (Zelensky) and the second position (Klychko) in the list. And the greatest attention towards internal affairs is considered (domestic focus is higher, than 2019 average).

As a result, it may be claimed, that the Ukrainian digital political discourse has been transforming, due to COVID-19 pandemic. The interrelations between the political actors was minimized, which may testify low engagement of non-official actors or their invisibility in the discourse.

Key words: digital political discourse, Ukraine, COVID-19, political text, «Ukrayins 'ka pravda» 